\title{
Human alterations of the terrestrial water cycle through land management
}

\author{
S. Rost, D. Gerten, and U. Heyder \\ Potsdam Institute for Climate Impact Research, Telegrafenberg A62, 14473 Potsdam, Germany \\ Received: 9 January 2008 - Revised: 26 March 2008 - Accepted: 28 May 2008 - Published: 20 June 2008
}

\begin{abstract}
This study quantifies current and potential future changes in transpiration, evaporation, interception loss and river discharge in response to land use change, irrigation and climate change, by performing several distinct simulations within the consistent hydrology and biosphere modeling framework LPJmL (Lund-Potsdam-Jena managed Land). We distinguished two irrigation simulations: a water limited one in which irrigation was restricted by local renewable water resources (ILIM), and a potential one in which no such limitation was assumed but withdrawals from deep groundwater or remote rivers allowed (IPOT). We found that the effect of historical land use change as compared to potential natural vegetation was pronounced, including a reduction in interception loss and transpiration by $25.9 \%$ and $10.6 \%$, respectively, whereas river discharge increased by $6.6 \%$ (climate conditions of 1991-2000). Furthermore, we estimated that about $1170 \mathrm{~km}^{3} \mathrm{yr}^{-1}$ of irrigation water could be withdrawn from local renewable water resources (in ILIM), which resulted in a reduction of river discharge by $1.5 \%$. However, up to $1660 \mathrm{~km}^{3} \mathrm{yr}^{-1}$ of water withdrawals were required in addition under the assumption that optimal growth of irrigated crops was sustained (IPOT), which resulted in a slight net increase in global river discharge by $2.0 \%$ due to return flows.

Under the HadCM3 A2 climate and emission scenario, climate change alone will decrease total evapotranspiration by $1.5 \%$ and river discharge by $0.9 \%$ in $2046-2055$ compared to 1991-2000 average due to changes in precipitation patterns, a decrease in global precipitation amount, and the net effect of $\mathrm{CO}_{2}$ fertilization. A doubling of agricultural land in 2046-2055 compared to 1991-2000 average as proposed by the IMAGE land use change scenario will result in a decrease in total evapotranspiration by $2.5 \%$ and in an increase in river discharge by $3.9 \%$. That is, the effects of land use change in
\end{abstract}

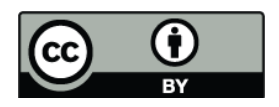

Correspondence to: $\mathrm{S}$. Rost (rost@ pik-potsdam.de) the future will be comparable in magnitude to the effects of climate change in this particular scenario. On present irrigated areas future water withdrawal will increase especially in regions where climate changes towards warmer and dryer conditions will be pronounced.

\section{Introduction}

There is growing evidence that humans are altering the global water cycle to an unprecedented and globally visible scale (Vörösmarty et al., 1997; Vörösmarty and Sahagian, 2000; Nilsson et al., 2005; Hanasaki et al., 2006; Haddeland et al., 2006; Shiklomanov and Rodda, 2003). One reason for these anthropogenic disturbances is the production of food and other commodities through irrigation; in fact, agriculture represents the sector with the largest water demand. Agricultural withdrawals represent about $70 \%$ of the total human water withdrawals, whereas agricultural water consumption (the part of withdrawals that evapotranspires and does not return to the river system) represents about $90 \%$ of the total water consumption (Gleick, 2003; Shiklomanov and Rodda, 2003). To fulfill human water demands, additional water resources are being increasingly exploited, e.g. fossil groundwater. Global information on the extraction of deep groundwater is poor, thus its influence on vapor flows and river discharge is largely unknown.

With a growing population, increasing welfare and changes in food patterns, the demand for food increased considerably during the recent decades. To accomplish for this demand, agricultural and irrigated areas were expanded and intensified (Ramankutty and Foley, 1999). In addition to the more direct effects of irrigation, these land use changes should also have affected evapotranspiration, infiltration rates, soil moisture patterns, and runoff generation. In fact, field studies showed that deforestation can cause substantial losses of water to the atmosphere due to

Published by Copernicus Publications on behalf of the European Geosciences Union. 
immediate reductions in interception loss and transpiration (Swift, jr. et al., 1975). Furthermore, several experiments and modeling studies demonstrated that river discharge increased as a consequence of forest clearance (Bosch and Hewlett, 1982; Sahin and Hall, 1996; Scanlon et al., 2007; Haddeland et al., 2007). There exist only a few studies which quantified changes in evapotranspiration due to deforestation and irrigation spatially explicitly and at continental or global scale (Döll and Siebert, 2002; Gordon et al., 2005; Haddeland et al., 2007). Future changes in both climate and land use are rarely addressed explicitly in water cycle studies at the global scale. Also, while many studies exist on effects of climate change on river discharge, mainly at river basin scale (e.g. Arnell, 2003, for global scale), studies on climate and land use change effects upon the individual components of evapotranspiration are virtually lacking. Moreover, only a few studies estimated the impact of climate change on irrigation water requirements (Döll, 2002; Fischer et al., 2007).

The aim of this paper is to globally quantify present and potential future interventions of humans on evaporation, interception loss, transpiration and river discharge within a consistent modeling framework. Furthermore, we quantified present and potential future water withdrawals for irrigation distinguished between renewable and non-renewable and/or allochthonous water resources. In a first step we investigated present-time effects of land use change and irrigation on the water fluxes. Then, we studied future effects of climate change and land use change on the water fluxes and on irrigation demand under a given climate and land use change scenario with fixed irrigated areas. The next section explains the model and the data used, and the simulations performed to quantify human modifications of the hydrological cycle. Thereafter we introduce and discuss our findings in comparison with previous studies. Finally we summarize and conclude our study.

\section{Methods}

\subsection{The LPJmL model}

To determine the diverse water fluxes we applied the wellestablished dynamic global vegetation and water balance model LPJmL (Lund-Potsdam-Jena managed Land), which has been extensively validated against biogeochemical and hydrological observations including leaf phenology, crop yields, river discharge, soil moisture, agricultural water consumption, and irrigation water use (e.g. Sitch et al., 2003; Gerten et al., 2004; Bondeau et al., 2007; Rost et al., 2008). LPJmL simulates global natural and agricultural vegetation, and the associated soil dynamics, carbon and water fluxes in a single framework. For this, key ecosystem processes such as photosynthesis, evapotranspiration, autotrophic and heterotrophic respiration, including the effects of soil moisture and drought stress, as well as allocation of assimilated car- bon to different above- and below-ground pools are implemented. Carbon fluxes and vegetation dynamics are directly coupled to water fluxes, in that e.g. photosynthesis and transpiration are treated as simultaneous processes (Sitch et al., 2003; Gerten et al., 2004).

Potential natural vegetation is represented by nine plant functional types (PFTs). PFTs can coexist in any grid cell, but their abundance depends on competition for light, water and space as well as on environmental (e.g. bioclimatic) constraints. Therefore, the distribution, fractional coverage and seasonal phenology of PFTs change depending on climate, water availability and fire occurrence (Sitch et al., 2003). On agricultural land, plant physiological and hydrological processes are simulated analogous to the PFTs using crop functional types (CFTs) (Bondeau et al., 2007). The world's most important field crops as well as pasture are represented by 12 CFTs. A grid cell may fractionally contain one stand for PFTs and several stands for agricultural vegetation which share the same climate and soil but have individual soil water budgets. The individual cover fractions of the stands are prescribed by the land use data set (see below). The growing season of individual CFTs is initiated by a temperature- or precipitation-dependent sowing date and ends with harvest when maturity is reached.

Cropland and grazing land can be either rainfed or irrigated. Irrigation water requirements were determined from the soil water deficit below optimal growth of the present CFTs and a country-specific irrigation efficiency to account for water losses on the way to the plant (for more details see Rohwer et al., 2007; Rost et al., 2008).

Precipitation and irrigation water are partitioned into soil moisture, transpiration, evaporation from soils and canopies, and river discharge. Soil moisture is calculated as the balance between the amount of water infiltrating into the soil (snowmelt, irrigation water, and precipitation minus interception loss from canopies) and that removed from the soil through surface and subsurface runoff, percolation, and evapotranspiration. Transpiration is calculated as a minimum function of soil water supply and atmospheric demand. The supply is determined as a function of potential evapotranspiration according to the Priestley-Taylor method, relative soil moisture, and rooting depth; whereas the demand is a function of potential evapotranspiration and potential canopy conductance as controlled by photosynthesis rate and ambient $\mathrm{CO}_{2}$ concentration. If soil water supply is lower than demand, canopy conductance, transpiration, and photosynthesis are reduced simultaneously (for more detail see Gerten et al., 2004). Soil evaporation occurs from bare soil and is determined as a function of potential evapotranspiration, and relative soil moisture. Lake evaporation is assumed to equal potential evapotranspiration. Interception loss is computed as a function of potential evapotranspiration, leaf area index, precipitation and irrigation water. River discharge is determined as accumulated surface and subsurface runoff along the river network (Rost et al., 2008). 


\subsection{Data}

LPJmL was run on a $0.5^{\circ}$ spatial resolution for the period 1901-2055, preceded by a 990-yr spin-up period to bring PFT distribution and carbon pools into equilibrium. Gridded monthly climate forcing data of monthly air temperature, precipitation and cloud cover were derived as anomalies from the HadCM3 scenario (IPCC, 2007) under the economyoriented SRES A2 emissions trajectory (Nakicenovic and Swart, 2000) and an extended CRU TS2.1 global climate dataset (Österle et al., 2003; Mitchell and Jones, 2005) for the period 1961 to 1990 . Sub-monthly weather variability was emulated using statistical procedures (Gerten et al., 2004). Soil information was derived from the FAO global database (FAO, 1991, details in Sitch et al., 2003). Annual fractional coverages with cropland were prescribed by a $0.5^{\circ}$ resolution dataset for the period 1901-1992 (Ramankutty and Foley, 1999). Thereafter the coverage was assumed to follow the trend of the last 20 years of that period until 2003. An A2-consistent future scenario of land use change patterns for rainfed agricultural land was derived from IMAGE (2001), whereas irrigated areas were kept constant at the 2003 value. The distribution of crop types within every grid cell was derived from Leff et al. (2004) for the year 1990 and interpolated backwards. The fraction of grazing land was approximated from the HYDE dataset (Klein Goldewijk and Battjes, 1997) for 1970 and also interpolated backwards. To assign irrigated cropland and pasture land we used a map of areas equipped for irrigation (Siebert et al., 2007). The river network topology was derived from the global $0.5^{\circ}$ drainage direction map DDM30 of Döll and Lehner (2002). To derive for each grid cell the area occupied by open freshwater bodies we used the global database of Lehner and Döll (2004).

\subsection{Simulations}

To distinguish present-time human alterations of the terrestrial water cycle, we performed four simulations for 19912000:

1. a simulation with potential natural vegetation, also on areas that are currently cropland or grazing land; PNV);

2. same as 1 . but with current distribution of cropland and grazing land, and without irrigation (INO);

3. same as 2. but with limited irrigation (ILIM) where water can only be withdrawn from renewable water, i.e. river discharge of the considered or one neighbor cell.

4. same as 2. but with full irrigation (IPOT) assuming that irrigated crops do not experience water stress. If irrigation demand exceeds the renewable water in IPOT, we assume that the remaining water is withdrawn from somewhere else (e.g. fossil groundwater, desalinization plants, river diversion).To provide an estimate of how water fluxes changed in response to both anthropogenic land cover conversion and irrigation, we compared the results of PNV and INO (to derive the isolated land cover change effect), of INO and ILIM (to derive the isolated irrigation effect), of ILIM and IPOT (to derive the effect of the use of non-renewable and/or allochthonous water resources), and of PNV and ILIM (to derive the joint effect of land cover change and irrigation) (see Table 1). To estimate future effects of climate and land use change on water flows and irrigation demand we performed four analogous simulations for the period 2046-2055:

5. same as 2. but assuming a constant land use fraction from 2003 (INO.CC);

6. same as 2. including land use change (INO.CC.LUC);

7. same as 6. but with limited irrigation (ILIM.CC.LUC); and

8. same as 6. but with potential irrigation (IPOT.CC.LUC). To provide an estimate of how future water fluxes may change in response to climate change, anthropogenic land cover conversion and irrigation, we compared the results of INO and INO.CC (to derive the isolated climate change effect), of INO.CC and INO.CC.LUC (to derive the isolated land cover change effect), of INO.CC.LUC and ILIM.CC.LUC (to derive the isolated irrigation effect), and of ILIM.CC.LUC and IPOT.CC.LUC (to derive the effect of the use of nonrenewable and/or allochthonous water resources) (see Table 1).

\section{Results and discussion}

\subsection{Effects of present land cover change}

We found that land cover change alone (INO minus PNV) decreased interception loss globally by $25.9 \%$ (ca. $2000 \mathrm{~km}^{3} \mathrm{yr}^{-1}$, Table 1), which reflects the decrease in canopy closure and in growing season as compared to the forest vegetation in the absence of human land use. Furthermore, transpiration decreased by $10.6 \%$ (ca. $4420 \mathrm{~km}^{3} \mathrm{yr}^{-1}$, Table 1). Deforestation has reduced transpiration for example due to shorter growing periods (i.e. intermittent periods with fallow land) and lower rooting depth of crops (as compared to the potential forests). These changes are apportioned differently to the diverse PFTs, with the deforestation of tropical forests having contributed most to the change (Fig. 1). Note, that the lower transpiration is partly counterbalanced by increased soil evaporation, so that overall evapotranspiration changes are small $(-3.8 \%$, Table 1$)$. The effect of deforestation resulted in an increase of river discharge of $2349 \mathrm{~km}^{3} \mathrm{yr}^{-1}$ in the INO simulation compared to PNV (Table 1). 
Table 1. LPJmL-simulated global transpiration, evaporation (sum of evaporation from soil, lakes, and canals), interception loss, total vapor flows (sum of evaporation, interception loss and transpiration), and river discharge as annual means 1991-2000 for the PNV, INO, ILIM, and IPOT simulations, and as annual means 2046-2055 for the INO.CC, INO.CC.LUC, ILIM.CC.LUC, and IPOT.CC.LUC simulations (in km ${ }^{3}$ $\left.\mathrm{yr}^{-1}\right)$.

\begin{tabular}{|c|c|c|c|c|c|}
\hline simulation & transpiration & evaporation & interception loss & total evapotranspiration & river discharge \\
\hline PNV & 41628 & 13102 & 7672 & 62403 & 35607 \\
\hline INO & 37207 & 17151 & 5685 & 60042 & 37956 \\
\hline $\begin{array}{l}\text { \% difference to PNV } \\
\text { (land cover change impact) }\end{array}$ & -10.6 & +30.9 & -25.9 & -3.8 & +6.6 \\
\hline ILIM & 37375 & 17455 & 5694 & 60525 & 37377 \\
\hline $\begin{array}{l}\% \text { difference to INO } \\
\text { (irrigation impact) }\end{array}$ & +0.5 & +1.8 & +0.2 & +0.8 & -1.5 \\
\hline $\begin{array}{l}\% \text { difference to PNV } \\
\text { (joint land cover change and irrigation impact) }\end{array}$ & -10.2 & +33.2 & -25.8 & -3.0 & +5.0 \\
\hline IPOT & 37695 & 17978 & 5694 & 61367 & 38143 \\
\hline $\begin{array}{l}\% \text { difference to ILIM } \\
\text { (impact of non-renewable/allochthonous water) }\end{array}$ & +0.9 & +3.0 & 0.0 & +1.4 & +2.0 \\
\hline INO.CC & 36154 & 16901 & 6103 & 59157 & 37598 \\
\hline $\begin{array}{l}\% \text { difference to INO } \\
\text { (climate change impact) }\end{array}$ & -2.8 & -1.5 & +7.4 & -1.5 & -0.9 \\
\hline INO.CC.LUC & 33670 & 18965 & 5064 & 57700 & 39049 \\
\hline $\begin{array}{l}\% \text { difference to INO.CC } \\
\text { (land cover change impact) }\end{array}$ & -6.9 & +12.2 & -17.0 & -2.5 & +3.9 \\
\hline ILIM.CC.LUC & 33864 & 19319 & 5077 & 58260 & 38391 \\
\hline $\begin{array}{l}\% \text { difference to INO.CC.LUC } \\
\text { (irrigation impact) }\end{array}$ & +0.6 & +1.9 & +0.2 & +1.0 & -1.7 \\
\hline IPOT.CC.LUC & 34206 & 19832 & 5099 & 59137 & 39154 \\
\hline $\begin{array}{l}\% \text { difference to ILIM.CC.LUC } \\
\text { (impact of non-renewable/allochthonous water) }\end{array}$ & +1.0 & +2.7 & +0.4 & +1.5 & +2.0 \\
\hline
\end{tabular}

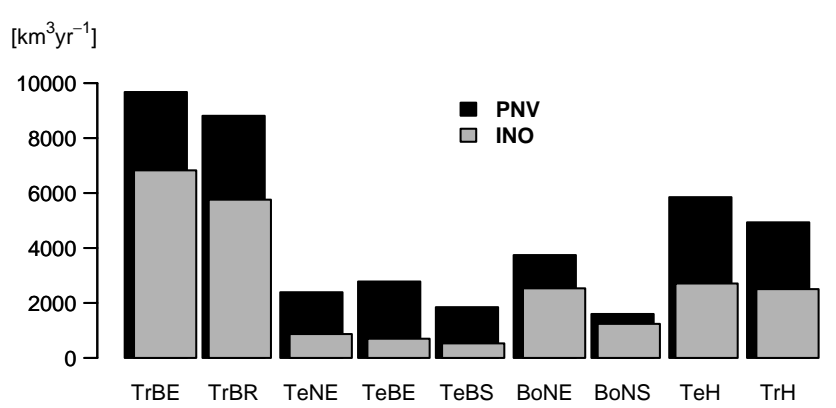

Fig. 1. PFT transpiration $\left(\mathrm{km}^{3} \mathrm{yr}^{-1}\right)$ for the PNV simulation (black) and the INO simulation (gray), 1991-2000 averages. TrBE: tropical broadleaved evergreen forest, TrBR: tropical broadleaved raingreen forest, TeNE: temperate needleleaved evergreen forest, TeBE: temperate broadleaved evergreen forest, TeBS: temperate broadleaved summergreen forest, BoNE: boreal needleleaved evergreen forest, BoNS: boreal needleleaved summergreen forest, $\mathrm{TeH}$ : temperate herbaceous (C3), TrH: tropical herbaceous (C4).

Gordon et al. (2005) estimated that total evapotranspiration for potential natural vegetation is $67000 \mathrm{~km}^{3} \mathrm{yr}^{-1}$ and that deforestation decreased global evapotranspiration by $3000 \mathrm{~km}^{3} \mathrm{yr}^{-1}$. Furthermore, Haddeland et al. (2007) reported a decrease in evapotranspiration in 1992 for North
America by $155 \mathrm{~km}^{3} \mathrm{yr}^{-1}$ and for Asia by $923 \mathrm{~km}^{3} \mathrm{yr}^{-1} \mathrm{com}-$ pared to historical (1700) values, which led to an increase in river discharge by about the same amounts. We estimated a decrease in evapotranspiration and therewith an increase in river discharge by $352 \mathrm{~km}^{3} \mathrm{yr}^{-1}$ for North America and by $838 \mathrm{~km}^{3} \mathrm{yr}^{-1}$ for Asia (INO minus PNV, data not shown). Similar to our study both studies used the cropland dataset of Ramankutty and Foley (1999), in which for North America no permanent croplands were assigned in 1700 . The more detailed description of CFTs in our study and the use of another approach to calculate total evapotranspiration might explain the different findings.

\subsection{Effects of present-time irrigation}

Due to withdrawal of surface water for irrigation river discharge decreased by $1.5 \%$ in the ILIM simulation compared to INO (Table 1). Due to irrigation, the different components of evapotranspiration increased to different extents (Table 1). The larger increase in soil evaporation can be explained by water losses from river to field, which are estimated by a country-specific conveyance efficiency (Rohwer et al., 2007; Rost et al., 2008). 


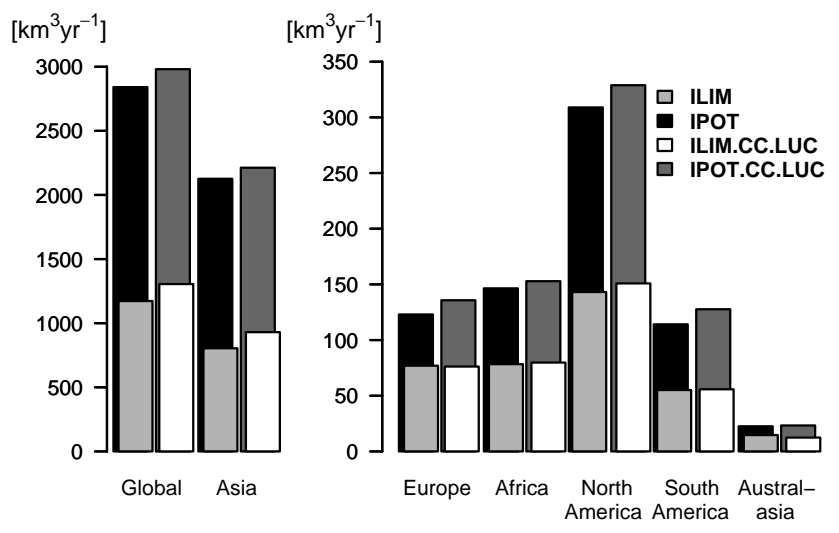

Fig. 2. Comparison of LPJmL-simulated water withdrawals for irrigation under present (1991-2000 averages) water limited (ILIM) and potential (IPOT) irrigation and under future (2046-2055 averages) water limited (ILIM.CC.LUC) and potential (IPOT.CC.LUC) irrigation $\left(\mathrm{km}^{3} \mathrm{yr}^{-1}\right)$.

Today about $1170 \mathrm{~km}^{3} \mathrm{yr}^{-1}$ of irrigation water requirements are withdrawn globally from renewable water (Fig. 2, ILIM simulation). An additional $1660 \mathrm{~km}^{3} \mathrm{yr}^{-1}$ of water withdrawals are required for optimal growth of irrigated crops (IPOT simulation). To fulfill this demand water has to be taken from other sources like fossil groundwater, river diversions or desalinization plants. The discrepancy in withdrawal between IPOT and ILIM represents non-renewable and/or allochthonous water use, and it varies slightly among continents (Fig. 2). Asia is the continent with the largest demand for irrigation water withdrawal $\left(2126 \mathrm{~km}^{3} \mathrm{yr}^{-1}\right.$, IPOT) and with the largest discrepancy between renewable water and irrigation water requirements $\left(1322 \mathrm{~km}^{3} \mathrm{yr}^{-1}\right.$, IPOT minus ILIM). This deficit is most severe in Northern India and North-West China (Fig. 3a).

Our estimate of $2830 \mathrm{~km}^{3} \mathrm{yr}^{-1}$ irrigation water withdrawal in IPOT is in good agreement with previous studies that exhibit a range from 2605 to $2942 \mathrm{~km}^{3} \mathrm{yr}^{-1}$ around the year 2000 (FAO, 2003; Shiklomanov and Rodda, 2003; Siebert and Döll, 2007). This implies that a major part of water for irrigation stemmed from non-renewable locally not accessible supplies (see Rost et al., 2008). Vörösmarty et al. (2005) suggested that 400 to $800 \mathrm{~km}^{3} \mathrm{yr}^{-1}$ of agricultural water withdrawal is non-sustainable. This is lower than our estimate, but might be partly explained by the larger surrounding area $\left(75 \mathrm{~km}^{2}\right)$ from which irrigation water can be withdrawn. Anyway, it is known that especially countries with large areas equipped for irrigation like China, India, and the US use fossil groundwater to a large degree (FAO, 2003) to balance the surface water deficit (Fig. 3a).

The use of additional water resources in the IPOT simulation resulted in a further increase in evapotranspiration of about $842 \mathrm{~km}^{3} \mathrm{yr}^{-1}$ compared to the ILIM simulation. Furthermore, river discharge increased by $766 \mathrm{~km}^{3} \mathrm{yr}^{-1}$ due to

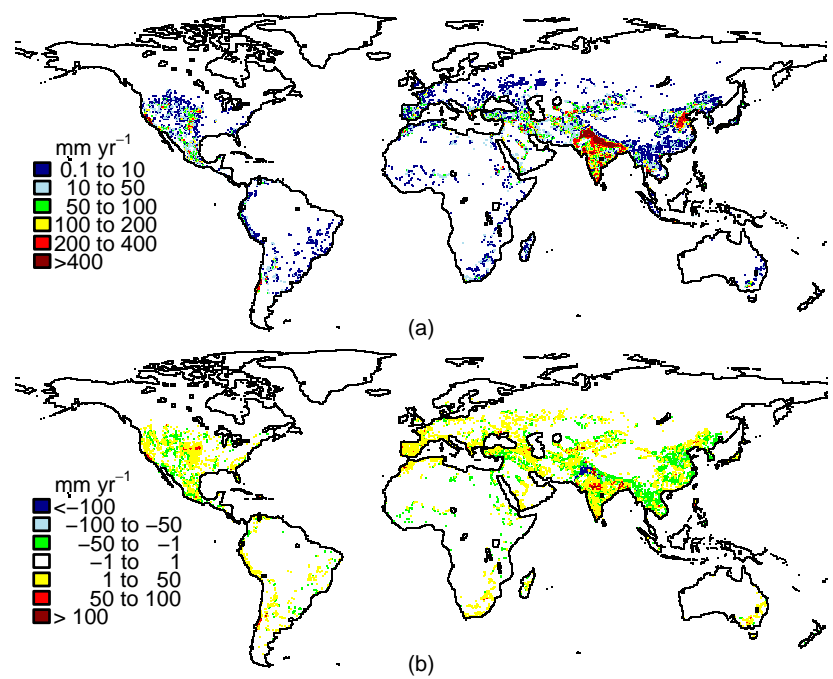

Fig. 3. (a) LPJmL-simulated discrepancy between potential (IPOT) and limited (ILIM) irrigation water withdrawals, 1991-2000 averages $\left(\mathrm{mm} \mathrm{yr}^{-1}\right)$. (b) Difference between future (2046-2055 averages) discrepancies of water withdrawals (IPOT.CC.LUC minus ILIM.CC.LUC, $\mathrm{mm} \mathrm{yr}^{-1}$ ) and (a).

return flows (Table 1). The latter amount may be slightly overestimated, as we did not simulate reservoir management and river diversions but assumed the irrigation water to be withdrawn from fossil groundwater or from desalinization plants.

\subsection{Joint effects of present land cover change and irrigation}

The combined effect of land use change and irrigation (PNV compared to INO) was estimated to decrease transpiration globally by $10.2 \%$ (Table 1 ). Regional large reductions in transpiration occurred due to land use change in regions with large agricultural areas, e.g. in parts of the US, Eastern Europe, southeast Australia, and in parts of India and China (Fig. 4a). The withdrawal of water for irrigation allows plants to grow where otherwise only poor vegetation growth is possible. Thus, transpiration increased along rivers like the Nile, Amur Darya, Indus, Euphrates, and Tigris in response to irrigation (Fig. 4a).

Global river discharge increased by $5.0 \%$ in the INO simulation compared to PNV (Table 1). Regional large percentage increases in river discharge occurred due to land use change, such as in parts of the US, China, and Australia (Fig. 4b). Water withdrawals for irrigation reduced river discharge especially in regions with large areas equipped for irrigation, such as in the Colorado, Rio Grande, Euphrates, Tigris, Syr Darya, Amur Darya, and Huang He basins (Fig. 4b). 


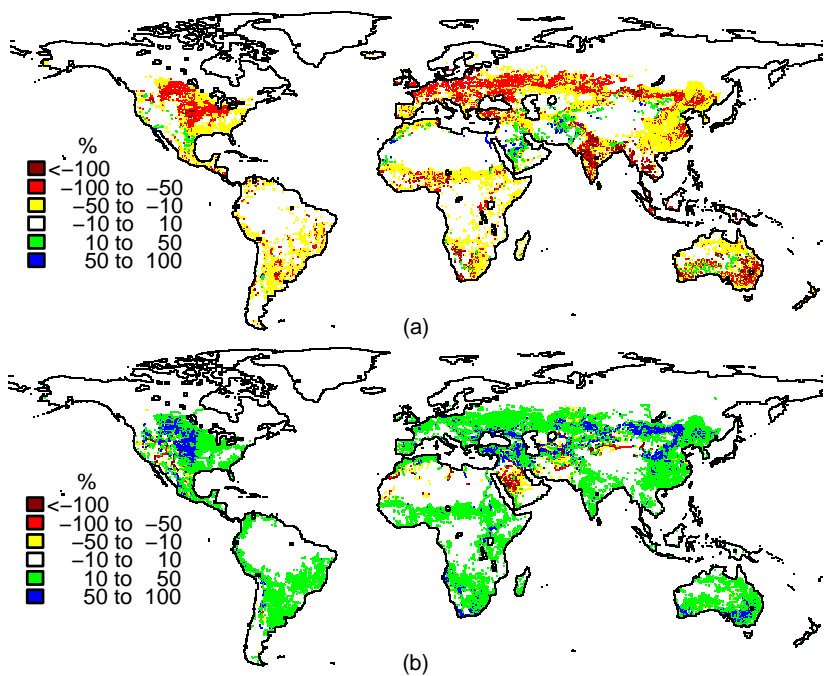

Fig. 4. LPJmL-simulated (a) transpiration and (b) river discharge as percentage difference of the PNV simulation to the ILIM simulation, showing the combined effect of land cover conversion and irrigation; 1991-2000 averages.

\subsection{Effects of climate and $\mathrm{CO}_{2}$ change}

To derive the effect of climate change on global water flows we compared INO and INO.CC. According to the chosen climate change scenario, transpiration and evaporation will decrease by $1053 \mathrm{~km}^{3} \mathrm{yr}^{-1}$ and $250 \mathrm{~km}^{3} \mathrm{yr}^{-1}$, respectively (Table 1). The reduction in evapotranspiration followed the patterns of decreasing precipitation in parts of Middle and South America, and in southern India (data not shown). In addition, the projected increase in future $\mathrm{CO}_{2}$ concentration resulted in a decrease in stomatal conductance and therewith transpiration. Interception loss increased globally by $418 \mathrm{~km}^{3} \mathrm{yr}^{-1}$, primarily as a result of an increasing leaf mass due to $\mathrm{CO}_{2}$ fertilization. Global river discharge decreased by $0.9 \%$ as a result of a decrease in total precipitation by $1346 \mathrm{~km}^{3} \mathrm{yr}^{-1}$.

\subsection{Effects of future land use change and irrigation}

To investigate future effects of land use change on global water fluxes we compared INO.CC and INO.CC.LUC. We estimated that an expansion of agricultural land and managed grassland in 2046-2055 (almost twice as large as in 1991-2000) will result in a further decrease in transpiration by $6.9 \%$ and in canopy evaporation by $17.0 \%$, while soil evaporation and river discharge will increase by $12.2 \%$ and by $3.9 \%$, respectively (Table 1 ). That is, the effect of land use change will be in the same order of magnitude or even stronger than the effect of climate change (at least in the particular scenario used), though the regional patterns of these effects will certainly differ.
We compared INO.CC.LUC and ILIM.CC.LUC as well as ILIM.CC.LUC and IPOT.CC.LUC to provide an estimate of the effect of climate change and land use change on irrigation requirements and availabilities under the assumption that irrigated areas remain constant. In the ILIM.CC.LUC simulation river discharge will decrease by $658 \mathrm{~km}^{3} \mathrm{yr}^{-1}$ $(1.7 \%)$ whereas total evapotranspiration will increase by $560 \mathrm{~km}^{3} \mathrm{yr}^{-1}(1.0 \%)$ compared to the INO.CC.LUC simulation (Table 1). About $1305 \mathrm{~km}^{3} \mathrm{yr}^{-1}$ of surface water will be withdrawn globally from rivers, lakes, and reservoirs. However, an additional $1661 \mathrm{~km}^{3} \mathrm{yr}^{-1}$ of water will have to be withdrawn for optimal crop growth. Furthermore, in the future the absolute amount of water withdrawal will increase under the considered climate change scenario in both ILIM/ILIM.CC.LUC (11.3\% globally) and IPOT/IPOT.CC.LUC (4.7\% globally) simulations (Fig. 2). The gap between the withdrawal under IPOT and ILIM shows regional differences. It will decrease mainly in the Indus basin, and simultaneously increase in parts of India (Fig. 3b). Thus, in the latter regions non-renewable and/or allochthonous water use will have to be increased to sustain crop growth.

Other climate and land use change scenarios (IPCC, 2007) may show different results. But our findings compare well to the results of Döll (2002), who found a small relative increase in global net irrigation requirement by $5.5 \%$ and $7.8 \%$, respectively, in 2070 compared to 1995 , depending on the climate projections (ECHAM3 and HADCM4, respectively, with forcing according to the IPCC IS92a scenario). Furthermore, Döll (2002) found regional shifts in irrigation demand patterns with the highest absolute increase in South Asia, which largely agrees with our findings.

Our assumption that irrigated areas will remain constant in the future is unrealistic, as these areas almost certainly will expand to some degree in many areas, but nonetheless we based our study on this assumption in order to show the separate effect of climate change on irrigation water demand. Further studies should include scenarios where irrigated areas on the one hand are adapted to population growth, technological development, and improvements in irrigation efficiency (like in Fischer et al., 2007), and on the other hand are shifted to more suitable regions to compensate regionally the negative impact of climate change.

\section{Conclusions}

This study shows that historical land use change resulted in a reduction of transpiration and interception loss, and in an increase in evaporation and in river discharge. Irrigation increased total evapotranspiration and reduced river discharge in a scenario that allowed only for the use of local renewable water (ILIM), but a scenario that allowed for the observed significant use of additional non-renewable and/or allochthonous water resources (IPOT) indicated that global 
river discharge actually increased relative to a non-irrigated simulation, due to return flows. The computed water withdrawals in the latter simulation compared well to previous studies, suggesting that currently about half of the irrigation water stems from non-renewable resources.

Climate change under the chosen projection resulted in a decrease in both total evapotranspiration and river discharge (INO.CC). This can be explained by the interplay between spatially distinct changes in precipitation patterns, a decrease in absolute precipitation amount, and the transpirationreducing effect of increased atmospheric $\mathrm{CO}_{2}$ content. Furthermore, we showed that an expansion of agricultural land in INO.CC.LUC will result in a reduction of transpiration and interception loss as well as an increase in evaporation and river discharge, with the magnitudes of change comparable to those of the climate change effects. Globally we found a slight increase in water withdrawal in both ILIM.CC.LUC and IPOT.CC.LUC simulations on present irrigated areas. In this study only one climate change projection was considered. Future investigations are required to estimate the range of changes in terrestrial water flows, irrigation requirements, and irrigation supplies under different emission scenarios, climate change projections, and rainfed and irrigated land use changes.

Acknowledgements. This study was funded by the Deutsche Forschungsgemeinschaft and the EC-funded ENSEMBLES project (contract GOCE-CT-2003-505539). It contributes to the implementation of Activity A-3.1 ("Water requirements for nature and humans") in the scientific framework of the Global Water System Project (GWSP). Thanks go to two anonymous reviewers and the editors of this special issue for valuable comments on an earlier manuscript version.

Edited by: F. Portmann, K. Berkhoff, and M. Hunger

Reviewed by: two anonymous referees and the editors

\section{References}

Arnell, N. W.: Effects of IPCC SRES* emissions scenarios on river runoff: a global perspective, Hydrol. Earth Syst. Sc., 7, 619-641, http://www.hydrol-earth-syst-sci.net/7/619/2003/, 2003.

Bondeau, A., Smith, P., Zähle, S., Schaphoff, S., Lucht, W., Cramer, W., Gerten, D., Lotze-Campen, H., Müller, C., Reichstein, M., and Smith, B.: Modelling the role of agriculture for the 20th century, Glob. Change Biol., 13, 679-706, doi:10.1111/j.13652486.2006.01305.x, 2007.

Bosch, J. and Hewlett, J.: A review of catchment experiments to determine the effect of vegetation changes on water yield and evapotranspiration, J. Hydrol., 55, 3-23, 1982.

Döll, P.: Impact of climate change and variability on irrigation requirements: A global perspective, Clim. Change, 54, 269-293, 2002.

Döll, P. and Lehner, B.: Validation of a new global 30-min drainage direction map, J. Hydrol., 258, 214-231, doi:10.1016/S00221694(01)00565-0, 2002.
Döll, P. and Siebert, S.: Global modeling of irrigation water requirements, Water Resour. Res., 38, 1037, doi:10.1029/2001WR000355, 2002.

FAO: The digitized soil map of the world (Release 1.0), Food and Agriculture Organization of the United Nations, Rome, Italy, 1991.

FAO: AQUASTAT online database, Rome, Italy, 2003.

Fischer, G., Tubiello, F. N., van Velthuizen, H., and Wiberg, D. A.: Climate change impacts on irrigation water requirements: Effects of mitigation, 1990-2080, Technol. Forecasting Soc. Change, 74, 1083-1107, doi:10.1016/j.techfore.2006.05.021, 2007.

Gerten, D., Schaphoff, S., Haberlandt, U., Lucht, W., and Sitch, S.: Terrestrial vegetation and water balance - hydrological evaluation of a dynamic global vegetation model, J. Hydrol., 286, 249-270, doi:10.1016/j.jhydrol.2003.09.029, 2004.

Gleick, P. H.: Water use, Annu. Rev. Env. Resour., 28, 275-314, 2003.

Gordon, L. J., Steffen, W., Jonsson, B. F., Folke, C., Falkenmark, M., and Johannessen, A.: Human modification of global water vapor flows from the land surface, Proc. Natl. Acad. Sci., 102, 7612-7617, doi:10.1073/pnas.0500208102, 2005.

Haddeland, I., Skaugen, T., and Lettenmaier, D. P.: Anthropogenic impacts on continental surface water fluxes, Geophys. Res. Lett., 33, L08406, doi:10.1029/2006GL026047, 2006.

Haddeland, I., Skaugen, T., and Lettenmaier, D. P.: Hydrologic effects of land and water management in North America and Asia: 1700-1992, Hydrol. Earth Syst. Sc., 11, 1035-1045, 2007.

Hanasaki, N., Kanae, S., and Oki, T.: A reservoir operation scheme for global river routing models, J. Hydrol., 327, 22-41, doi:10.1016/j.jhydrol.2005.11.011, 2006.

IMAGE: The IMAGE 2.2 implementation of the SRES scenarios: A comprehensive analysis of emissions, climate change and impacts in the 21st century, RIVM CD-ROM Publ. 481508018, Bilthoven, Netherlands, 2001.

IPCC: Fourth Assessment Report, Technical Summary of the Working Group I Report, 2007.

Klein Goldewijk, K. and Battjes, J. J.: A hundred year (1890-1990) database for integrated environmental assessments (HYDE, version 1.1), National Institute of Public Health and the Environment (RIVM), Bilthoven, The Netherlands, 1997.

Leff, B., Ramankutty, N., and Foley, J. A.: Geographic distribution of major crops across the world, Global Biogeochem. Cy., 18, GB1009, doi:10.1029/2003GB002108, 2004.

Lehner, B. and Döll, P.: Development and validation of a global database of lakes, reservoirs and wetlands, J. Hydrol., 296, 1-22, doi:10.1016/j.jhydrol.2004.03.028, 2004.

Mitchell, T. D. and Jones, P. D.: An improved method of constructing a database of monthly climate observations and associated high-resolution grids, Int. J. Climatol., 25, 693-712, doi:10.1002/joc.1181, 2005.

Nakicenovic, N. and Swart, R., eds.: Special Report on Emisson Scenarios, Cambridge Univ. Press, New York, 2000.

Nilsson, C., Reidy, C. A., Dynesius, M., and Revenga, C.: Fragmentation and flow regulation of the world's large river systems, Science, 308, 405-408, 2005.

Österle, H., Gerstengarbe, F. W., and Werner, P. C.: Homogenisierung und Aktualisierung des Klimadatensatzes der Climate Research Unit der Universität of East Anglia, Norwich, 
in: Terra Nostra, 6. Deutsche Klimatagung, Potsdam, Germany, 2003.

Ramankutty, N. and Foley, J. A.: Estimating historical changes in global land cover: Croplands from 1700 to 1992, Glob. Biogeochem. Cy., 13, 997-1027, doi:10.1029/1999GB900046, 1999.

Rohwer, J., Gerten, D., and Lucht, W.: Development of functional types of irrigation for improved global crop modelling, PIK Report, 104, Potsdam Institute for Climate Impact Research, Potsdam, 2007.

Rost, S., Gerten, D., Bondeau, A., Lucht, W., Rohwer, J., and Schaphoff, S.: Agricultural green and blue water consumption and its influence on the global water system, Water Resour. Res., in press, 2008.

Sahin, V. and Hall, M. J.: The effects of afforestation and deforestation on water yields, J. Hydr., 178, 293-309, 1996.

Scanlon, B. R., Jolly, I., Sophocleous, M., and Zhang, L.: Global impacts of conversions from natural to agricultural ecosystems on water resources: Quantity versus quality, Water Resour. Res., 43, W03437, doi:10.1029/2006WR005486, 2007.

Shiklomanov, I. A. and Rodda, J. C., eds.: World water resources at the beginning of the twenty-first century, Cambridge University Press, 2003.

Siebert, S. and Döll, P.: Global change: Enough water for all?, chap. 2.4 Irrigation water use - A global perspective, pp. 104-107, Wissenschaftliche Auswertungen/GEO Hamburg, 2007.
Siebert, S., Döll, P., Feick, S., Hoogeveen, J., and Frenken, K.: Global map of irrigation areas version 4.0.1, Johann Wolfgang Goethe University, Frankfurt am Main, Germany/FAO, Rome, Italy, 2007.

Sitch, S., Smith, B., Prentice, I. C., Arneth, A., Bondeau, A., Cramer, W., Kaplan, J. O., Levis, S., Lucht, W., Sykes, M. T., Thonicke, K., and Venevsky, S.: Evaluation of ecosystem dynamics, plant geography and terrestrial carbon cycling in the LPJ dynamic global vegetation model, Glob. Chang. Biol., 9, 161$185,2003$.

Swift, jr., L. W., Swank, W. T., Mankin, J. B., Luxmoore, R. J., and Goldstein, R. A.: Simulation of Evapotranspiration and Drainage From Mature and Clear-Cut Deciduous Forests and Young Pine Plantation, Water Resour. Res., 11, 667-673, 1975.

Vörösmarty, C. J. and Sahagian, D.: Anthropogenic Disturbance of the Terrestrial Water Cycle, BioScience, 50, 753-765, doi:10.1641/0006-3568(2000)050[0753:ADOTTW]2.0.CO;2, 2000.

Vörösmarty, C. J., Sharma, K. P., Fekete, B. M., Copeland, A. H., Holden, J., Marble, J., and Lough, J. A.: The storage and aging of continental runoff in large reservoir systems of the world, AMBIO, 26, 210-219, 1997.

Vörösmarty, C. J., Lévêque, C., and Revenga, C.: Fresh Water, in: Ecosystems and human well-being: Current states and trends, edited by Bos, R., Chaudill, C., and et al., J. C., pp. 165-207, Millenium Ecosystem Assessment Report, Island Press, 2005. 